\title{
Capital Controls: Myth and Reality A Portfolio Balance Approach to Capital Controls
}

\author{
Nicolas E. Magud \\ University of Oregon \\ Carmen Reinhart \\ University of Maryland and NBER \\ Kenneth Rogoff \\ Harvard University and NBER
}

May 2007

Working Paper 2007-31

http://www.frbsf.org/publications/economics/papers/2007/wp07-31bk.pdf

The views in this paper are solely the responsibility of the authors and should not be interpreted as reflecting the views of the Federal Reserve Bank of San Francisco or the Board of Governors of the Federal Reserve System. This paper was produced under the auspices of the Center for Pacific Basin Studies within the Economic Research Department of the Federal Reserve Bank of San Francisco. 


\title{
Capital Controls: Myth and Reality
}

\section{A Portfolio Balance Approach to Capital Controls}

\author{
Nicolás E. Magud, Carmen Reinhart, and Kenneth Rogoff*
}

This draft: May 2007

First draft: December 2005

\begin{abstract}
The literature on capital controls has (at least) four very serious apples-to-oranges problems: (i) There is no unified theoretical framework to analyze the macroeconomic consequences of controls; (ii) there is significant heterogeneity across countries and time in the control measures implemented; (iii) there are multiple definitions of what constitutes a "success" and (iv) the empirical studies lack a common methodology-furthermore these are significantly "overweighted" by a couple of country cases (Chile and Malaysia). In this paper, we attempt to address some of these shortcomings by: being very explicit about what measures are construed as capital controls. Also, given that success is measured so differently across studies, we sought to "standardize" the results of over 30 empirical studies we summarize in this paper. The standardization was done by constructing two indices of capital controls: Capital Controls Effectiveness Index (CCE Index), and Weighted Capital Control Effectiveness Index (WCCE Index). The difference between them lies in that the WCCE controls for the differentiated degree of methodological rigor applied to draw conclusions in each of the considered papers. Inasmuch as possible, we bring to bear the experiences of less well known episodes than those of Chile and Malaysia. Then, using a portfolio balance approach we model the effects of imposing short-term capital controls. We find that there should exist country-specific characteristics for capital controls to be effective. From these simple perspective, this rationalizes why some capital controls were effective and some were not. We also show that the equivalence in effects of price- vs. quantitycapital control are conditional on the level of short-term capital flows.
\end{abstract}

Keywords: Capital Controls.

JEL Classification: F30.

${ }^{*}$ University of Oregon, University of Maryland and NBER, and Harvard University and NBER, respectively. 


\section{Introduction}

The literature on capital controls has (at least) four very serious issues that make it difficult, if not impossible, to compare across theoretical and empirical studies. We dub these the apples-to-oranges problems and they include: (i) There is no unified theoretical framework (say, as in the currency crisis literature) to analyze the macroeconomic consequences of controls; (ii) there is significant heterogeneity across countries and time in the capital control measures implemented; (iii) there are multiple definitions of what constitutes a "success" (capital controls are a single policy instrumentbut there are many policy objectives); and (iv) the empirical studies lack a common methodology and are furthermore significantly "overweighted" by the two poster children-Chile and Malaysia.

Our goal in this paper is to find a common ground among the non-comparabilities in the existing literature. Of course, there is usually a level of generality that is sufficiently encompassing. After all, an apples-to-oranges problem can be solved by calling everything fruit. Our goal is, as far as possible, to classify different measures of capital controls on a uniform basis. Once done, it should be easier to understand the cross-country and time-series experience.

We attempt to address some of these apples-to-oranges shortcomings by being very explicit about what measures are construed as capital controls. We document not only the more drastic differences across countries/episodes and between controls on inflows and outflows, but also the more subtle differences in types of inflow or outflow controls. Also, given that success is measured so differently across studies, we standardize (wherever possible) the results of over 30 empirical studies summarized in this paper. Inasmuch as possible, we bring to bear the experiences of episodes less well known than those of Chile and Malaysia.

The standardization was done by constructing two indexes of capital controls: Indices of Capital Controls Effectiveness (CCE), and Weighted Capital Control Effectiveness (WCCE). The difference between them lies only in the fact that the WCCE controls for the differentiated degree of methodological rigor applied to draw conclusions in each of the papers considered.

Our results with these indexes can be summarized briefly. Capital controls on inflows seem to make monetary policy more independent, alter the composition of capital flows, and reduce real exchange rate pressures (although the evidence there is more controversial). Capital controls on inflows seem not to reduce the volume of net flows (and hence the current account balance). 
As to controls on outflows, there is Malaysia and there is everybody else. In Malaysia, controls reduced outflows and may have given room for more independent monetary policy (the other poster child does not fare as well, in that our results are not as conclusive as for the Chilean controls on inflows). Absent the Malaysian experience, there is little systematic evidence of "success" in imposing controls, however defined.

All of the above implies that either imposing capital controls on inflows or outflows need not always be effective. In a sense, this paper identifies "initial conditions" under which controls on capital flows can be effective.

The next step consists in rationalizing what we have learnt in a simple and tractable model. We do this by using a portfolio balance approach to capital controls. The latter describes foreign investors that have to decide under uncertainty the share of their portfolio investment to allocate in short- vs. long-term flows. The main conclusion of the model is that conditional on the elasticity of short-term capital flows to total capital flows, the same capital controls could result in either an increased, unaltered or decreased level of short-term flows as well total capital flows. Thus, it is not clear that capital controls-even if exactly equally implemented-in two countries will necessarily be as effective (or effective at all!). We also model the conditions under which price-capital-controls (taxes imposed on the rate of return of short-term capital flows) generate the same effect on capital controls as quantity-capital-controls (restrictions to the quantity of capital flows permitted). Interestingly, we find that that its effectiveness depends on the level of short-term capital flows at the moment that the controls are put in place. Thus, we obtain a model that shows that only under very specific conditions will capital controls be effective in achieving its goals, as the first part of the paper documents.

The paper proceeds as follows. The next section summarizes some of the key reasons why capital controls-particularly capital controls on inflows-are either considered or implemented. Controls, as we note, help deal with what we dub the "four fears". Section 3 focuses on the distinctions among types of capital controls-highlighting the fact that not all capital control measures are created equal and therefore they can not be simply lumped together in a rough capital controls index. Section 4, examines the existing empirical evidence by standardizing and sorting studies along a variety of criteria. Specifically, we focus on the following sorting strategy. First, we analyze separately cases 
where the study was multicountry or focused on a single case study; second, we distinguish the cases where the controls were primarily designed to deal with inflows or outflows; third, we provide an ad hoc (but uniform) criteria to rank the approach or econometric rigor applied in the study to test hypotheses about the effects of the controls; and, last, we evaluate the outcomes reported in the studies according to the definition of what constitutes a success. Then, Section 5 models the above situations using a portfolio balance approach. The last section discusses some of the policy implications of our findings.

\section{The Rational for Capital Controls and the "Four Fears"}

Anyone examining the literature on capital controls, which spans many decades and all the regions around the globe, would be well advised to retain a sense of irony. Repeatedly, policymakers have sought refuge in tax laws, supervisory restraint, and regulation of financial transactions to cope with external forces that they deem to be unacceptable. Often they rationalize their actions on loftier grounds, sometimes so effectively as to make it difficult to clearly identify episodes of controls on capital. But in all these episodes, four fears lurk beneath the surface.

\subsection{Fear of Appreciation}

Being the darling of investors in global financial centers has the decided, albeit often temporary, advantage of having ample access to funds at favorable cost. With the capital inflow comes upward pressure on the exchange value of the currency, rendering domestic manufacturers less competitive in global markets, and especially so relative to their close competitors who are not so favored as an investment vehicle. A desire to stem such an appreciation (which Calvo and Reinhart, 2002, refer to as "fear of floating") is typically manifested in the accumulation of foreign exchange reserves. Over time, though, sterilizing such reserve accumulation (the topic of Reinhart and Reinhart, 1998) becomes more difficult, and more direct intervention more appealing.

\subsection{Fear of "Hot Money"}

For policymakers in developing countries, becoming the object of foreign investors' attention is particularly troubling if such affection is viewed as fleeting. The sudden injection of funds into a 
small market can cause an initial dislocation that is mirrored by the strains associated with their sudden withdrawal. Such a distrust of "hot money" was behind James Tobin's initial proposal to throw sand in the wheels of international finance, an idea that has been well received in at least some quarters. Simply put, a high-enough tax (if effectively enforced) would dissuade the initial inflow and pre-empt the pain associated with the inevitable outflow.

\subsection{Fear of Large Inflows}

Policymakers in emerging market economies do not universally distrust the providers of foreign capital. Not all money is hot, but sometimes the sheer volume of flows matters. A large volume of capital inflows, particularly when it is sometimes indiscriminate in the search for higher yields (in the manner documented by Calvo, Leiderman, and Reinhart, 1994), causes dislocations in the financial system. Foreign funds can fuel asset price bubbles and encourage excessive risk taking by cash-rich domestic intermediaries. Again, recourse to taxation may seem to yield a large benefit.

\subsection{Fear of Loss of Monetary Autonomy}

The interests of global investors and domestic policymakers need not always-or even often-align. But a trinity is always at work. It is not possible to have a fixed (or highly managed) exchange rate, monetary policy autonomy, and open capital markets (as discussed in Frankel, 2001). If there is some attraction to retaining some element of monetary policy flexibility, something has to give up. However, in the presence of the aforementioned fear of floating, giving up capital mobility may seem more attractive than surrendering monetary policy autonomy.

Whatever the reason for action, some forms of capital control were intended to control exchange rate pressures, stem large inflows, and regain an element of monetary autonomy. And this is more relevant for those policymakers who impose controls to reduce capital flight, because investors seeking safety-including, most important, domestic residents as well as foreigners-are seldom dissuaded by regulatory restraint. 


\section{Capital Controls? What Do We Mean by Capital Controls?}

In most of the empirical literature there are no distinctions between controls on outflows and controls on inflows-these exercises suffer from the same problems as the de jure IMF classification of exchange rate arrangements. Even when a distinction is made between inflows and outflows (as here), controls can and do range from the explicit to the subtle, from the market friendly to the coercive. $^{1}$

Furthermore, when considering the impacts and effectiveness of capital controls one cannot lump together the experiences of countries that have not substantially liberalized (i.e., India and China) with countries that actually went down the path of financial and capital account liberalization and decided at some point to reintroduce controls, as the latter have developed institutions and practices that are integrated in varying degrees to international capital markets.

Tables 1-2, which squarely focus on measures targeted to affect inflows and outflows in countries that had already gone the route of capital account liberalization, ${ }^{2}$ indeed highlight the heterogeneity in both subtlety and "market-friendliness" of capital control measures that have been tried in Asia, Europe, and Latin America during booms (these involve controls on capital inflows) as well as crashes (and attempts to curb capital outflows). These measures differ not only in subtlety and other features but also in intensity ${ }^{3}$

\section{[Insert Tables 1 and 2 about here]}

\section{The Empirical Literature: Finding a Common Ground}

This section aims to overcome (or at least take a step in that direction) two of the apples-to-oranges problems we have identified in the capital controls literature. Namely, we attempt to: (i) ascertain when and in what capacity capital controls were "successful" in achieving the stated objectives of the authorities (this is not trivial, as what constitutes as a success is defined very differently across

\footnotetext{
${ }^{1}$ There is, of course, the important issue of temporary versus permanent policies which is a distinction not addressed here owing to the fact that most empirical studies do not focus on this issue. For a model and a discussion of the temporary versus permanent issue see Reinhart and Smith (2002).

${ }^{2}$ Hence, these cases involve the reintroduction of controls.

${ }^{3}$ For a measure that "quantifies" the intensity of these measures see Montiel and Reinhart (1999).
} 
studies), and (ii) standardize (to some extent) the very eclectic array of descriptive and empirical methodologies and approaches that have characterized the empirical literature on capital controls. Lastly, we bring to bear evidence on lesser well known episodes other than the "classics" (Chile's controls on inflows starting in 1990 and Malaysia's 1998 controls on outflows).

In what follows, we review more than 30 papers that study capital controls on either inflows or outflows around the world. Some are country case studies, some describe several individual country experiences, and some are multicountry studies that bunch several cases together. As noted earlier, the papers measure "success" differently; thus, our aim is to standardize methodology and results where possible so as to facilitate comparisons. Not only will this enable us to assess the effectiveness of alternative capital controls events, but it will also permit us to evaluate some of the policy implications of imposing controls on capital inflows and/or outflows under alternative scenarios.

\subsection{Types of Studies}

We proceed as follows. First, we cluster the papers into three broad groups: (i) capital inflows (CI), (ii) capital outflows (CO); and (iii) multi-country (MC)-the latter including the analysis of capital inflows, capital outflow, or both. We collected studies of capital controls for the following countries (the number of papers is shown in parentheses): For CI, there are studies on: Brazil (6), Chile (11), Colombia (3), the Czech Republic (1), Malaysia (2), and Thailand (1). For CO, we obtained information for Malaysia (5), Spain (3), and Thailand (2). For the MC group, we collected five papers, covering a wide array of countries. ${ }^{4}$

\subsection{Objective(s) of capital controls}

Given the multiple objectives that capital controls are expected to achieve, we approached paper with a series of questions. We asked whether, according to each paper, capital controls were able to

1. Reduce the volume of capital flows

\footnotetext{
${ }^{4}$ For example, one of the more comprehensive multi-country papers uses monthly data for the period 1971-1998 for a panel of 26 countries.
} 
2. Alter the composition of capital flows (towards longer maturity flows)

3. Reduce real exchange rate pressures

4. Allow for a more independent monetary policy

As a first step in sorting this information, we constructed Tables 3, 4, and 5. Table 3 includes CI episodes, Table 4 displays $\mathrm{CO}$ episodes, and Table 5 focuses in MC studies. As can be seen in the tables, possible answers are YES, NO, or a blank space. If the table reads YES in any cell, it means that the paper finds that the corresponding objective of capital controls was achieved. NO stands for the paper finding that there was not such effect as a result of the capital controls. A blank space means that the paper does not address whether there was an effect. Sometimes the answer is followed by (ST). This indicates that the effects were only temporary, i.e. that an objective was achieved only in the Short Term. To give an example, in Table 3, the paper by Laurens and Cardoso (1998) studying the case of the Chilean experience during the 1990's, finds evidence that capital controls were able to reduce the volume of capital flows only in the short term, that they were able to alter the composition of these flows toward longer maturity flows, and that they were not successful in reducing pressures on the real exchange rate. They do not report results regarding the effectiveness of capital controls in making monetary policy more independent.

In a first pass through this information, by inspection, we can summarize it as follows (see Table $6)$. We observe that in general, the results obtained in these papers suggest that capital controls were successful in altering the composition of capital flows toward longer maturities and in making monetary policy more independent. However, the papers are not very informative regarding the effectiveness of capital controls in reducing the volume of capital flows and reducing real exchange rate pressures.

\subsection{Indices of Capital Control Effectiveness}

But this is not informative enough, since it still lacks some rigor to evaluate the effectiveness of capital controls episodes. In order to better understand this, we construct two indexes of capital controls effectiveness. We call them the Capital Controls Effectiveness Index (CCE Index), and the Weighted Capital Controls Effectiveness Index (WCCE Index). The only difference in com- 
puting them is that the WCCE Index weighs the results obtained in each paper by the degree of methodological rigor applied to drawing conclusions; we discuss thus further below.

In both cases, following the information summarized in Tables 3-5, we arbitrarily assigned the following values:

If the answer is YES, the corresponding value is 1.

If the answer is NO, the value assigned is -1 .

If the question is not addressed at all, it corresponds to a value of 0 .

These values are designed to equally weigh the existence or non existence of effects as a result of the imposition of capital controls and to give no weight to questions not addressed, so as not to distort the results in case any objective of capital controls is not addressed by the paper.

With these values at hand, for each country we computed simple averages of these numbers for each of the four questions we brought to the papers. This gives, for example, a CCE Index for volume reduction for each country, a CCE Index for real exchange rate pressure reduction for each country, and so on. With this information we are able to compare, for each objective, which country was most effective.

We also used this information to compute an aggregate index of capital controls effectiveness, by averaging out the four CCE Indexes for each country, and then compare a global CCE Index across countries.

However, as has already been mentioned, the methodology used in these papers to evaluate success is highly heterogeneous. Some papers are mainly descriptive, generating conclusions from the movements (or lack thereof) in the time series of the main variables, and lack any rigorous statistical or econometric analysis. Other papers use some statistical or econometric methodology to evaluate capital control, but events among them, there is still wide variation in the degree of rigor used to extract conclusions from the data.

In order to control for these differences, we made another pass through the information in the papers. We classify each study according to the degree of methodological rigor in, LOW, INTERMEDIATE, and HIGH according to the following criteria:

Low: This includes studies that consist mainly of descriptive analysis of events and/or time series. 
Intermediate: This groups papers that draw conclusions from a more formal evaluation of events but still lack any formal hypothesis testing. An example would be papers that perform time re-scaling to compare the effects of capital controls in a "before capital controls" and "after capital controls" analysis.

High: This includes only those studies that have highly developed econometric techniques, with a well defined hypothesis testing.

Table 7 (in the Appendix) summarizes the methodology used in each paper, as well as the corresponding classification as Low, Intermediate, High, following these definitions.

In order to compute the WCCE Index, we assigned the following values:

Low: 0.1

Intermediate: 0.5

High: 1.

With these values at hand, we compute the WCCE Index similarly to the CCE Index, in order to determine which country has been most effective in achieving each of the four objectives. We also compute an aggregate (per country) WCCE Index. This enables us to understand which countries capital controls were more useful in. Furthermore, given this information we can, at least as a first approximation, find conditions under which capital controls tend to be effective. Once more, it is worth mentioning that these exercises were done separately for the 3 clusters into which we separated the papers: CI, CO, and MC.

\subsection{Summary of Results}

Summary results of the CCE and WCCE Indexes are presented in Table 8 (Panels A, B and C). From these indexes, we can extract the following policy conclusions. Looking at the data on controls on inflows (Panel A) along with the preliminary results in Table 6, we see that capital controls were able to make monetary policy more independent, alter the composition of capital flows toward longer maturities, and reduce real exchange rate pressures (although the evidence on the latter is more controversial). Interestingly, the usual model economy for this type of controls, Chile, stands out as achieving these goals quite comfortably, as the WCCE Index shows. In this regard, initial conditions or characteristics such as those in Chile in the early 1990's, along with the continuing 
reforms during the 1990's, appear to be necessary conditions in order for capital controls on inflows to be effective. On the other hand, capital controls on inflows were not very effective in reducing the volume of net flows (hence the impact of these flows on the current account balance).

Looking in more detail, we see that Malaysia (1994) stands out as the best performer in terms of reducing the volume of capital flows, Chile dominates regarding the change in capital flows maturity, Thailand is superior in respect to reducing real exchange rate pressures, and Chile again dominates in regard to monetary policy independence. Overall, as the average of the WCCE Index reflects, Chile emerges as the most successful example of capital controls on inflows.

Let us now focus on capital controls on outflows (Panel B), the received wisdom is that Malaysia (1997) is the example to follow. From our results, we can see that these capital controls were effective in reducing capital outflows and in making monetary policy more independent. Yet, the results from WCCE Index are not as conclusive as those on the Chilean controls on inflows.

If we focus on the reduction in capital flows, Thailand and Spain dominate Malaysia. Regarding the switch in capital flows towards longer maturity, no conclusion can be extracted. Spain emerges as the best in real exchange rate pressures reduction; on the other hand, Malaysia clearly dominates at making monetary policy more independent. On the aggregate, Malaysia appears to be the most successful in its experience of capital controls on outflows.

Some further comments are in order. First, it could be argued that these indexes are not taking into account many other variables that might be affecting the effectiveness of capital controls, especially the set of "other" reforms being put in place in each country during each capital controls episode. That is true. However, this paper is reviewing and assessing only the conclusions contained in previous papers, not the papers themselves. All the reviewed papers draw conclusions from their information sets, and we just put them together and try to extract the main message that these papers give as a group. Furthermore, it is precisely because of this "omitted variables bias" type of problem is that our WCCE Index becomes more relevant. For example, any structural reform carried on in parallel with capital controls is not usually specifically reflected in the papers we review; in a sense, for us this is similar to running a regression with missing data that we have to control for. This is where the degree of methodological rigor becomes important. The more formal the analysis is, especially if it includes hypothesis testing, the more accurate the information 
contained in it.

Second, a similar reasoning applies to the endogeneity of capital controls. Some could argue that we should control for it. Again, we rely on the conclusions obtained in previous papers, thus giving more value to the results we obtain from WCCE Index. Also, this is relevant for how controls on capital inflows affect capital outflows. Moreover, that is why we cluster CI and CO separately in our analysis.

Third, it is worth mentioning that the papers we review are clearly not the only ones dealing with capital controls. There are many papers that analyze the long-run effects of capital controls, whereas we focus on the short-run only, as can be seen from the questions with which we approach the papers.

Fourth, another interesting point is whether capital control regimes are transitory or permanent. Here, as the questions we focus on clearly reveal, we are interested only in transitory events. This is why episodes such as the Chinese or Indian approach to capital controls are not covered here; see the papers on these countries contained in the NBER volume edited by Sebastian Edwards for this purpose.

Fifth, an interesting point to raise is related to the timing (and related endogeneity) of capital controls: whether they are imposed in response to events-crises-or if they are designed in advance. Here, once more, we lack information because we rely only on what the papers conclude. It is worth mentioning, though, that by inspection it appears that the Malaysian (1997) episode could have been designed in advance, unlike most of the other episodes, and contrary to common wisdom. This theory emerges from the chronologies given in Tables 1 and 2. In the case of Malaysia (1997), a great quantity of controls were imposed on September 1st, 1997. Furthermore, the level of detail in seems to suggest that they were not decided upon and designed just in response to the crises.

Sixth, sometimes temporary capital control events become permanent. This could be because of time consistency problems or just because of the current response to future changes: rational expectations call for incorporating into your current decision the fact that in a pre-specified time period capital controls will be levied. Furthermore, even if a country imposed capital controls and did relax them at the pre-established date, this might work as a signal that capital controls could be imposed in the future if needed. However, this signal says nothing about the controls being 
either good or bad-many things will influence the latter, especially the controls' effectiveness, as well as their effects on property rights. At any rate, imposing capital controls once establishes a precedent regarding a country's position toward capital mobility, despite the costs and benefits of such controls. This is another dimension in which temporary capital controls might become "permanent".

[Insert Tables 3, 4, 5, 6, 7, 8, and 9 about here]

\section{A Portfolio Balance Approach to Capital Controls}

Received wisdom from previous sections thus suggests that temporary capital controls should deliver the following:

- Alter capital flows composition towards longer maturities

- Reduce capital flows

- Generate monetary policy independence through interest rates differentials

- Reduce real exchange rate pressures

This section develops a simple model to explain why these should be the outcome of imposing capital controls, separating controls on capital inflows and on capital outflows.

We study a two-period small open economy that receives a flow of external capital in period $t$ of size $F_{t}$. For simplicity, these flows will be either short term flows, $S_{t}$, or long term flows, $L_{t}$. The random real rate of return on these capital flows are $r$ for long term capital flows and $r^{*}$ for short terms flows. Given risk parameters, without loss of generality, we assume throughout that $r^{*}>r$.

$$
F_{t}=S_{t}+L_{t}
$$

Short term flows represent a share $x$ of total capital flows, such that

$$
S_{t}=x F_{t}
$$

where $x$ is endogenous and results from the optimization program of foreign investors. 


\subsection{Foreign Investors}

There is a unit mass of foreign investors. Given the random nature of the rates of return on each type of capital flows, the optimization problem is characterized in terms of solving an expected utility maximization in terms of means and variances-covariances. The representative agent will solve for the portfolio composition of these capital flows in terms of the parameters of the model such as its risk preferences. Thus, the agent solves the following problem:

$$
\max _{x} U=U\left(\bar{w}, \sigma_{w}^{2}\right)
$$

where the expected rate of return on capital flows, $\bar{w}$, is given by

$$
\bar{w}=(1+r) F_{t}+\left(r^{*}-r\right) x F_{t}
$$

and the variance by

$$
\sigma_{w}^{2}=F_{t}^{2}\left[(1-x)^{2} \sigma_{r}^{2}+x^{2} \sigma_{r^{*}}^{2}+2 x(1-x) \sigma_{r r^{*}}\right]
$$

where $\sigma_{i}^{2}$ stands for the variance of variable $i$ and $\sigma_{i j}$ refers to the covariance between $i$ and $j$.

From the FOC's, we obtain

$$
x=\frac{\left(r^{*}-r\right)+\Phi\left(\sigma_{r}^{2}-\sigma_{r r^{*}}\right)}{\Phi \sigma}
$$

where $\sigma=\left(\sigma_{r}^{2}+\sigma_{r^{*}}^{2}-2 \sigma_{r r^{*}}\right)$, and $\Phi$ represents the coefficient of risk aversion.

Notice that the share of capital flows devoted to short term flows increase with the yield differential and decreases with risk aversion, in line with standard portfolio selection models.

Alternatively, we can write this as

$$
x=\frac{r^{*}-r}{\Phi \sigma^{2}}+\alpha
$$

where 


$$
\alpha \equiv \frac{\sigma_{r}^{2}-\sigma_{r r^{*}}}{\sigma^{2}}
$$

Were $\alpha$ represents the share of capital flows to minimize the variance of flows. Equation (7) separates the speculative component of this flows share and the component that corresponds to minimize the portfolio variance. The latter depends only on the relative riskiness of each type of capital flow.

\subsection{Capital Controls on Inflows}

Let's modify slightly the above set up to incorporate capital controls on inflows. Without loss of generality, assume that capital controls, $\tau$, can take on only two values: 0 for no capital controls, and $\bar{\tau}$ if capital controls do exist. Namely,

$$
\tau= \begin{cases}0 & \text { if } \nexists \text { capital controls } \\ \bar{\tau}>0 & \text { if } \exists \text { capital controls }\end{cases}
$$

where $0<\bar{\tau}<1$. Let's now re-define the real return on short term flows as $r^{\prime *}$, such that the aftercapital-controls real rate of return on short term flows is now given by $\left(1+r^{*}\right)=\left(1+r^{*}\right)(1-\tau)$.

\section{Maturity Structure of Capital Flows}

Given this very simple framework, we now proceed to analyze the outcome of imposing capital controls on inflows. Suppose the economy starts with no capital control and unexpectedly imposes capital controls on inflows. Simply put, this represents a decrease in $r^{*}$. The result is summarized in Proposition 1.

Proposition 1. Imposing capital controls reduces the share of short-term capital flows.

Proof: Notice that from (7), we observe that

$$
\frac{d x}{d r^{*}}=\frac{1}{\Phi \sigma}>0
$$


This implies that as a result of imposing capital controls, external financing in the form of short term capital flows is reduced-i.e the relative size of long term flows, $L$, increases.

\section{Aggregation}

The analysis above refers to each individual investor. This subsection aggregates over the economy. We assume for simplicity that agents share the information but have potentially different wealth and/or risk aversion, which are idiosyncratic characteristics.

Total demand for short term flows for investor $j$ with wealth $W_{j}$ is given by $x_{j} W_{j}$-where, as mentioned, $x_{j}$ in conditional on the individual investor's risk aversion. The economy's aggregate wealth is given by

$$
\bar{W}=\sum_{j} W_{j}
$$

In equilibrium, aggregate demand for short-term flows should equal aggregate supply for these flows, as follows:

$$
V^{*}=\sum_{j} x_{j} W_{j}
$$

Now, for each individual $j$, multiply $(7)$ by $W_{j}$ on both sides and then aggregate over $j$ to obtain

$$
\sum_{j} x_{j} W_{j}=\left(\frac{r^{*}-r}{\sigma^{2}}\right) \sum_{j} \frac{W_{j}}{\Phi_{j}}+\alpha \sum_{j} W_{j}
$$

Plugging (12) and (11) in (13) results in

$$
V^{*}=\left(\frac{r^{*}-r}{\sigma^{2}}\right) \sum_{j} \frac{W_{j}}{\Phi_{j}}+\alpha \bar{W}
$$

where, after some manipulation we obtain

$$
r^{*}-r=\Phi \sigma^{2}\left(\frac{V^{*}}{\bar{W}}-\alpha\right)
$$


and where we have defined $\Phi \equiv \sum_{j} \frac{\Phi_{j}}{W_{j} / \bar{W}}$ as the aggregate risk aversion.

With the latter, we can state Proposition 2, which is just the aggregate of Proposition 1:

Proposition 2. In the aggregate, introducing capital control results in a reduction of short-term capital flows as a share of total capital flows.

Proof: analogous to Proposition 1

$$
\frac{\partial r^{*}}{\partial\left(V^{*} / \bar{W}\right)}=\Phi \sigma^{2}>0
$$

Notice that so far we have just shown that in response to imposing capital controls, the share of short-term flows to total flows decreases. However, we still have to explain if this results from a reduction in the level of short-term flows, an increase in the level of total flows, or both. For the moment we can thus safely state that imposing capital controls on short term flows increases the maturity structure of capital flows, but not necessarily reduce the level of capital flows. This is consistent with the evidence in this paper as well as in Magud and Reinhart (2005). Next section analyzes this by focusing on the determinants of the composition of capital flows.

\section{Determinants}

We want to further analyze the conditions under which the above mentioned reactions to capital controls hold.

Notice that all else equal, capital control generates a higher level of capital flows. This can be shown by computing the partial derivative of (15) to obtain

$$
\frac{\partial r^{*}}{\partial \bar{W}}=-\frac{\Phi \sigma V^{*}}{\bar{W}^{2}}<0
$$

The intuition for the latter is that for an investor (or the aggregate market) to obtain the same expected rate of return in response to the introduction of capital controls, total capital flows should increase.

However, the more interesting results emerge by looking at totally differentiation of (15), which looks as follows: 


$$
\mathrm{d} r^{*}=\Phi \sigma^{2}\left[\frac{\bar{W} \mathrm{~d} V^{*}-V^{*} \mathrm{~d} \bar{W}}{\bar{X}^{2}}\right]
$$

(18) can be manipulated to obtain the following two expressions:

$$
\frac{\mathrm{d} r^{*}}{\mathrm{~d} V^{*}}=\Phi \sigma^{2}\left[1-\frac{1}{\eta}\right]
$$

and

$$
\frac{\mathrm{d} r^{*}}{\mathrm{~d} \bar{W}}=\frac{V^{*} \Phi \sigma^{2}}{\bar{W}}[\eta-\bar{W}]
$$

where $\eta \equiv \frac{\mathrm{d} V^{*}}{\mathrm{~d} W} \frac{\bar{W}}{V^{*}}$ stands for the elasticity of short term capital flows with respect to total capital flows.

These expressions are then summarized in two new propositions.

Proposition 3. The effects of imposing capital controls on short term capital flows depend on the elasticity of short term capital flows with respect to total capital lows such that:

1. For $0<\eta<1: \quad \frac{d r^{*}}{d V^{*}}<0 \quad$ Short term capital flows levels increase

2. For $\eta=1: \quad \frac{d r^{*}}{d V^{*}}=0$ Short term capital flows levels remain unaltered

3. For $\eta>1: \quad \frac{d r^{*}}{d V^{*}}>0$ Short term capital flows levels decrease

Proof: see (19)

Proposition 4. The effects of imposing capital controls on short term capital flows depend on the elasticity of short term capital flows with respect to total capital lows such that:

1. For $0<\eta<\bar{W}: \quad \frac{d r^{*}}{d \bar{W}}<0 \quad$ Total capital flows levels increase

2. For $\eta=\bar{W}: \quad \frac{d r^{*}}{d \bar{W}}=0$ Total capital flows levels do not change

3. For $\eta>\bar{W}: \quad \frac{d r^{*}}{d \bar{W}}>0 \quad$ Total capital flows levels decrease 
Proof: see (20)

The interesting point of Propositions 3 and 4 is that, unlike common wisdom, it is not necessarily the case that by introducing capital controls the maturity structure of the economy will lengthen and that capital flows will be instantaneously reduced. The conditions under which these happen are not trivial. In turn, this supports the wide variety of the results-and many times of contradicting

nature-that the empirical literature has found, as surveyed in Magud and Reinhart (2005), and complemented in this paper.

For example, Proposition 4 reflects the facts that only for sufficiently large values of $\eta$ we will able to observe a reduction in the volume of capital flows resulting from imposing capital controls. This is also consistent with the mentioned survey in which the evidence shows how many times capital controls were able to reduce capital flows, but some other they were not. In this regard, a separate paper could empirically asses the value of $\eta$ to verify if the countries for which capital controls were successful correspond to those with high $\eta$-and those with lower $\eta$ were not able to reduce capital flows.

Also, as Proposition 3 shows, not every capital control episode should necessarily be able to increase the maturity of capital flows. However, given that the evidence is more conclusive in that more times that not capital controls were able to achieve this objective, it is probably the case that for many of the countries that put these controls in place the value of $\eta$ was greater than 1 .

\section{Quantity vs. Price Restrictions}

Given the diversity observed in terms of alternative capital controls episodes, one interesting question to analyze is what is the required tax rate on rates on returns that should be imposed to obtain any specific level of change in the maturity composition of capital flows? To answer this question we return to (15). Re-writing it in slightly different way:

$$
X=\frac{r^{*}-r}{\Phi \sigma^{2}}+\alpha
$$

where $X$ stands for the aggregate share of short term capital in total aggregate capital. For any change in $X$ and $r^{*}$, observe that: 


$$
\Delta X=\frac{1}{\Phi \sigma^{2}} \Delta r^{*}
$$

Manipulating (22), we obtain:

$$
\frac{\Delta X / X}{\Delta r^{*}}=\frac{1}{X \Phi \sigma^{2}}>0
$$

Notice how (23) established the percentage change in the volume of capital flows that will be obtain by any percentage change in the rate of return on short term capital flows, namely by imposing capital controls. This semi-elasticity reflects how much each percentage point of capital controls reduces the volume of short term flows.

This leads us to our next proposition:

Proposition 5. Conditional on the aggregate volume of short-term capital flows observed in the instant prior to the application of capital controls, there exists a quantity restriction of capital flows that will generate the same effects on capital flows as imposing taxes on the rate of return on short term capital flows.

Proof: see (23)

Notice the importance of the latter proposition in that the quantitative restriction depend on the level of short term flows when the controls are imposed. The higher the volume of aggregate short term flows, the smaller the level restrictions should be to generate a similar effect as controls on rates of return.

\section{Monetary Policy Independence}

The reduction in capital flows also creates a wedge in interest rates, giving the central bank an increased monetary independence to implement counter-cyclical policies. This results directly from the expression that defines the relation between short term interest rates before and after capital controls, $\left(1+r^{*}\right)=\left(1+r^{*}\right)(1-\tau)$. In the presence of capital controls the wedge is given by the rate of taxation on the real rates of return, such that $r^{*}>r^{*}$. 


\section{Real Exchange Rate Pressures}

Given domestic savings, the current account will be financed entirely by external capital flows, such that,

$$
F=\bar{W}=C A(e), C A^{\prime}<0
$$

where $e$ represents the real exchange rate. The latter expression states that if the economy experiences a current account deficit, in equilibrium, the real exchange rate will depreciate. ${ }^{5}$

If the economy is unexpectedly under capital controls, we already showed that capital flows will be reduced. This reduces the current account deficit. In equilibrium, this should drive the exchange rate up, i.e. a real depreciation, to equilibrate the current account in the presence of less capital flows to finance the domestic economy.

Notice how the analysis of Propositions 3 and 4 directly extend to observing whether capital control are able or not to affect the real exchange rate.

\subsection{Capital Controls on Outflows}

For controls on capital outflows, the analysis is simpler since these types of controls, by definition, focus on restricting the volume of capital trying to leave the country. In terms of the above model, an easy way to represent this is by a reduction in $\bar{W}$, exogenously imposed. All else equal, inspection of (15) directly reveals that

$$
\frac{\mathrm{d} V^{*}}{\mathrm{~d} \bar{W}}=\frac{V^{*}}{\bar{W}}
$$

Which can be summarized in the following proposition:

Proposition 6. The marginal unit of short term flows is allocated in to keep the average share of short term capital flows constant.

Proof: see (25)

\footnotetext{
${ }^{5}$ This relationship is easy to obtain from first principles by just assuming a two-good economy in which the production function of tradables is increasing in the real exchange rate and non-tradable output is either exogenously given or decreasing in the real exchange rate. Alternatively, it can be obtained by solving the domestic consumer's problem in a two-good economy -either by introducing a cash-in advance constraint or money in the utility function.
} 
Thus, imposing these controls can reduce the volume of capital outflows, but cannot change the maturity structure of these flows. Regarding exchange rates and monetary policy, the results for capital controls on inflows remains the same. The latter result is also consistent with the evidence that we document.

\section{Conclusions}

In sum, capital controls on inflows seem to: make monetary policy more independent; alter the composition of capital flows; and reduce real exchange rate pressures (although the evidence here is more controversial). ${ }^{6}$ Capital controls on inflows, however, seem not to reduce the volume of net flows (and, hence, the current account balance).

As for controls on capital outflows, there is Malaysia ... and there is everybody else. In Malaysia, controls reduce outflows and may make room for more independent monetary policy. ${ }^{7}$ There is little evidence of "success" in other countries attempting to control outflows, either in terms of altering the volume or regaining monetary policy independence. These findings are in line with those of the earlier literature focused on capital flight (as in Mathieson and Rojas-Suarez, 1996) and dual or parallel exchange markets (an in Kiguel, Lizondo, and O'Connell 1997).

While the effectiveness of controls varies across time, country, and type of measures used, limiting private external borrowing in the "good times" plays an important prudential role, because more often than not countries are "debt intolerant". Indeed, often the critical problem in good times is that countries borrow too much! ${ }^{8}$

While our study has made the case for the need to distinguish measures primarily designed to discourage inflows from those that primarily aim at curbing outflows, it would be worthwhile for future research to attempt to ascertain whether there are also important differences in achieving "success" between measures that are more market friendly (as in the Chilean reserve requirements) versus those that are based on more blunt quantitative restrictions. Furthermore, in this study, owing to the nature of most of the empirical work reviewed here (which treats the control measures as single episodes), it would be interesting for policy purposes to examine differences between short

\footnotetext{
${ }^{6}$ According to the WCCI, Chile stands out in achieving these goals.

${ }^{7}$ Yet, the results for Malaysia based on the WCCI are not as conclusive as for the Chilean controls on inflows.

${ }^{8}$ See Reinhart, Rogoff, and Savastano (2003) for details.
} 
run and long run impacts of the measures, to ascertain how quickly control measures lose their effectiveness.

As long as capital flows to emerging markets remain volatile and potentially disruptive, the discussion of capital controls in academic and policy circles will remain alive, and hence there is a real need to evaluate their effectiveness, however defined. As noted earlier, it is an old discussion. Tobin's seminal paper dates back to the 1970s. Furthermore, capital controls have historically been used to deal with the fickle capital flow cycle for at least two hundred years. Indeed, as in past inflow episodes, at the time of this writing countries like Colombia and Argentina either have implemented controls on capital inflows or are contemplating doing so. 


\section{References}

Alfiler, F. Enrico, "Monetary and Exchange Rate Policy Responses to Surges in Capital Flows: The Case of the Philippines", paper prepared for the Eleventh Pacific Basin Central Bank Conference held in Hong Kong, October 31-November 2, 1994.

Ariyoshi, Akira, Karl Habermeier, Bernard Laurens, Inci Okter-Robe, Jorge Canales-Kriljenko, and Anderi Kirilenko, "Capital Controls: Country Experiences with Their Use and Liberalization", International Monetary Fund Occasional Paper 190, 2000.

Calvo, Guillermo A., Leonardo Leiderman, and Carmen M. Reinhart, "The Capital Inflows Problem: Concepts and Issues," Contemporary Economic Policy, Vol. XII No. 3, July 1994, 54-66.

Calvo, Guillermo A. and and Carmen M. Reinhart, "Fear of Floating," Quarterly Journal of Economics, Vol. CXVII No. 2, May 2002, 379-408.

Cardoso and Goldfajn, "Capital Flows to Brazil: The Endogeneity of Capital Controls", IMF Satff Papers, Vol. 45, March 1998.

De Gregorio, Jos, Sebastian Edwards, and Rodrigo Valds, "Controls on Capital Inflows: Do They Work?" Journal of Development Economics, Vol. 3 No. 1, 2000, 59-83.

DeKaplan, Ethan and Dani Rodrik, "Did the Malaysian Capital Controls Work?" in S. Edwards and J. Frankel, eds., Preventing Currency Crises in Emerging Markets, (Chicago: University of Chicago Press for the NBER, 2002).

Dornbusch, Rudi, "Malaysia: Was It Different?" National Bureau of Economic Research Working Paper 8325, June 2001.

Edwards, Sebastian, "Capital Controls and Capital Flows in Emerging Economies: Policies, Practices, and Consequences, National Bureau of Economic Research, University of Chicago Press, forthcoming 2006.

Edwards, Sebastian, "How Effective Are Controls on Capital Inflows? An Evaluation of Chile's Experience," Mimeograph, UCLA, June 1999. 
Edwards, Sebastian, "How Effective are Capital Controls?" Journal of Economic Perspectives Vol. 13 No.4, Fall 1999, 65-84.

Edwards, Sebastian and Roberto Rigobon, "Capital Controls, Managed Exchange Rates, and External Vulnerability," Mimeograph, UCLA, February 2004.

Edison, Hali and Carmen Reinhart, "Stopping Hot Money: On the Use of Capital Controls during Financial Crises", Journal of Development Economics, Vol. 66 No. 2 December 2001, 533-553.

Gallego, F., Hernandez and Schmidt-Hebbel , "Capital Controls in Chile: Effective? Efficient?" Central Bank of Chile Working Paper \#59 (December), 1999.

Kiguel, M., J. Saul Lizondo and Stephen O'Connell (eds.) "Parallel Exchange Rates in Developing Countries", London:MacMillan and New York: St. Martin's, 1997.

Labán, Raul M., and Felipe Larran, "The Return of Private Capital to Chile in the 1990s: Causes, Effects, and Policy Reactions," Faculty Research Working Paper Series R98-02, JFK School of Government, Harvard University, January 1998.

Laurens and Cardoso, "Managing Capital Flows: Lessons from the Expience of Chile" IMF Working Paper 98, 1998.

Mathieson and Rojas Suarez "Liberalization of the Capital Account: Experiences and Issues", IMF Occasional Paper 103, 1993.

Le Fort, Guillermo, and Carlos Budnevich, "Capital Account Regulations and Macroeconomic Policy: Two Latin Experiences," Mimeograph, Banco Central de Chile, March 1997.

Magud, Nicolás, and Carmen Reinhart, "Capital Controls: An Evaluation", in Capital Controls and Capital Flows in Emerging Economies: Policies, Practices, and Consequences, National Bureau of Economic Research, Sebastian Edwards (editor), University of Chicago Press, forthcoming 2006.

Miniane, Jacques and John Rogers, "Capital Controls and the International Transmission of U.S. Money Shocks," Board of Governors of the Federal Reserve, mimeograph, June 2004. 
Montiel, Peter and Carmen M. Reinhart (1999), "Do Capital Controls and Macroeconomic Policies Influence the Volume and Composition of Capital Flows? Evidence from the 1990's," Journal of International Money and Finance, Vol. 18 No. 4, August, 619-635.

Reinhart, Rogoff, and Savastano "Debt Intolerance", Brookings Papers on Economic Activity, Vol. 1 Spring 2003, 1-74.

Reinhart, Carmen and Todd Smith (1998), "Too Much of a Good Thing: The Macroeconomic Effects of Taxing Capital Inflows," in Reuven Glick, ed. Managing Capital Flows and Exchange Rates: Perspectives from the Pacific Basin, (Cambridge: Cambridge University Press), 436-464.

Reinhart, Carmen and Todd Smith, "Temporary Controls on Capital Inflows", Journal of International Economics, Vol. 57 No. 2, December 2002, 327-351.

Tamirisia, Natalia, "Do Macroeconomic Effects of Capital Controls Vary by Their Type? Evidence from Malaysia", International Monetary Fund Working Paper 04/3, January 2004.

Tobin, James, "A Proposal for International Monetary Reform”, Eastern Economic Journal, 4, pp. 153-59, 1978.

Valds-Prieto, Salvador, and Marcelo Soto, "New Selective Capital Controls in Chile: Are They Effective? Mimeograph, Universidad Catlica de Chile, September 1995.

Vinals, Jose, "Spains Capital Account Shock", mimeograph, CEPR, 1992. 
Table1. Restrictions on Inflows and "Prudential Requirements:” Asia

Country and date (in parentheses) denoting the first year of the surge in inflows

\section{Indonesia (1990)}

March, 1991: Central Bank adopts measures to discourage offshore borrowing. Bank Indonesia begins to scale down its swap operations by reducing individual banks' limits from 25 to 20 percent of capital. The three-month swap premium was raised by 5 percentage points.

October, 1991: All state-related offshore commercial borrowing was made subject to prior approval by the Government and annual ceilings were set for new commitments over the next five years.

November, 1991: Further measures are taken to discourage offshore borrowing. The limits on banks' net open market foreign exchange positions were tightened by placing a separate limit on off-balance sheet positions.

Bank Indonesia also announced that future swap operations (except for "investment swaps" with maturities of more than two years) would be undertaken only at the initiative of Bank Indonesia.

\section{Malaysia (1989)}

June 1, 1992: Limits on non-trade-related swap transactions were imposed on commercial banks.

January 17, 1994-August 1994: Banks were subject to a ceiling on their non-trade- or noninvestment-related external liabilities.

January 24, 1994-August 1994: Residents were prohibited from selling short-term monetary instruments to nonresidents.

February 2, 1994-August 1994: Commercial banks were required to place with Bank Negara the ringgit funds of foreign banking institutions (Vostro accounts) held in non-interest bearing accounts. However, in the January-May period these accounts were considered part of the eligible liabilities base for the calculation of required reserves, resulting in a negative effective interest rate in Vostro balances.

February 23, 1994-August 1994: Commercial banks are not allowed to undertake non-trade related swap and outright forward transactions on the bid side with foreign customers.

\section{Philippines (1992)}

July, 1994: Bangko Central begins to discourage forward cover arrangements with non-resident financial institutions.

\section{Thailand (1988)}

Banks and finance companies net foreign exchange positions may not exceed 20 percent of capital. Banks and finance companies net foreign liabilities may not exceed 20 percent of capital. Residents are not allowed to hold foreign currency deposits except only for trade-related purposes. April, 1990: Banks and finance companies net foreign exchange positions limit raised to 25 percent of capital.

August 8, 1995: Reserve requirements, to be held in the form of non-interest bearing deposits at the Bank of Thailand, on short-term non-resident baht accounts were raised from 2 percent to 7 percent. While reserve requirements on domestic deposits are also 7 percent, up to 5 percent can be held in the form of interestbearing public bonds.

December 1995: The 7 percent reserve requirement is extended to finance companies short-term (less than one year) promissory notes held by non-residents.

A variety of measures aimed at reducing foreign-financed lending were introduced.

April 19, 1996: Offshore borrowing with maturities of less than 1 year by commercial banks, BIBF offices, finance companies and finance and security companies will be subject to a 7-percent minimum reserve requirement in the form of a nonremunerated deposit with the Bank of Thailand. Loans for trade purposes will be exempt.

Sources: Alfiler (1994), Bank Indonesia, Annual Report, various issues, Bank Negara, Annual Report, various issues, and Bank of Thailand reports, various issues. 
Table1. (continued) Restrictions on Inflows and Prudential Requirements: Eastern Europe
and Latin America

\section{Country and date (in parentheses) denoting the first year of the surge in inflows}

\section{Brazil (1992)}

October, 1994: A 1 percent tax on foreign investment in the stock market. Eliminated on March 10, 1995. The tax on Brazilian companies issuing bonds overseas was raised from 3 percent to 7 percent of the total. Eliminated on March 10, 1995.

The tax paid by foreigners on fixed interest investments in Brazil was raised from 5 percent to 9 percent. Reduced back to 5 percent on March 10, 1995.

The Central Bank raised limits on the amount of dollars that can be bought on foreign exchange markets.

Chile (1990)

June, 1991: Nonrenumerated 20 percent reserve requirement to be deposited at the Central Bank for a period of one year on liabilities in foreign currency for direct borrowing by firms.

The stamp tax of 1.2 percent a year (previously paid by domestic currency credits only) was applied to foreign loans as well. This requirement applies to all credits during their first year, with the exception of trade loans. May, 1992: The reserve requirement on liabilities in foreign currency for direct borrowing by firms is raised to 30 percent. Hence, all foreign currency liabilities have a common reserve requirement.

\section{Colombia (1991)}

June, 1991: A 3 percent withholding tax on foreign exchange receipts from personal services rendered abroad and other transfers, which could be claimed as credit against income tax liability.

February, 1992: Banco de la Republica increases its commission on its cash purchases of foreign exchange from 1.5 percent to 5 percent.

June, 1992: Regulation of the entry of foreign currency as payment for services.

September, 1993: A nonrenumerated 47 percent reserve requirement to be deposited at the Central Bank on liabilities in foreign currency for direct borrowing by firms. The reserve requirement is to be maintained for the duration of the loan and applies to all loans with a maturity of 18 months or less, except for trade credit. August, 1994: Nonrenumerated reserve requirement to be deposited at the Central Bank on liabilities in foreign currency for direct borrowing by firms. The reserve requirement is to be maintained for the duration of the loan and applies to all loans with a maturity of five years or less, except for trade credit with a maturity of four months or less. The percentage of the requirement declines as the maturity lengthens; from 140 percent for funds that are 30 days or less to 42.8 percent for five year funds.

\section{Colombia (2002)}

December, 2004: Foreigners investing in domestic markets must now keep their money in the country for at least one year.

\section{Czech Republic (1992)}

April, 1995: The central bank introduced a fee of 0.25 percent on its foreign exchange transactions with banks, with the aim of discouraging short-term speculative flows.

August 1, 1995: A limit on net short-term (less than one year) foreign borrowing by banks is introduced. Each bank is to ensure that its net short-term liabilities to nonresidents, in all currencies, do not exceed the smaller of 30 percent of claims on nonresidents or Kc 500 million.

Administrative approval procedures seek to slow down short-term borrowing by nonbanks.

\section{Mexico (1990)}

April, 1992: A regulation that limited foreign currency liabilities of commercial banks to 10 percent of their total loan portfolio was passed. Banks had to place 15 percent of these liabilities in highly liquid instruments. Sources: Banco Central de Chile, (1991 and 1992), Banco de la Republica, Colombia (1993 and 1994), Banco de Mexico (1992), and Conselho Monetario Nacional, Brasil (1994 and 1995). 
Table 2. Restrictions on Outflows: Asia, Europe, and Latin America

\title{
Country and date (in parentheses) denoting the first year of the surge in outflows (or crisis)
}

\begin{abstract}
Argentina (crisis ending the Convertibility Plan, 2001)
December, 2001: The Corralito is established, limiting bank withdrawal limits and restrictions on dollar transfers and loans. However, purchases through checks or credit cards available, and purchases of government bonds. Dec.30: suspension of external payments (debt default). January 2002 there is a $40 \%$ devaluation and a dual exchange rate regime is introduced (1.4 pesos per dollar for trade operations, while floating regime for all other transactions. Later in the month, there is an. easing of bank withdrawals restrictions followed by an asymmetric pesofication. Pesofication of dollar deposits at 1.4 pesos per dollar; dollar debts pesofied at market exchange rate; unification of exchange rate regimes in a floating scheme; right to withdraw wages and pension incomes in full; Corralon is imposed: freeze of bank term deposits. In September of that year it is required that stocks should be traded in domestic currency regulation. Since the latter is widely resisted, it was eased, but the new restriction significantly increased transactions costs. In December 2002 the Corralito is rescinded.
\end{abstract}

Brazil, (crisis ending the Real Plan, 1999)

March 1999: Government ordered local investment funds to increase their holdings of government bonds. The central bank raised to 80 percent from 60 percent the minimum amount of sovereign debt that must be held in the country foreign investment fund. This lowered the share that could be held in other countries' debt.

Malaysia (Asian crisis, 1997)

September, 1998:: Bank and foreign exchange controls limiting offshore swap operations, ban on shortselling. 1998: repatriation of ringgit held offshore, and strict regulation on offshore operations and most international operations in ringgit, export and import operations allowed in foreign currency only, 12-month waiting period for non-residents to sell profits from Malaysian securities, approval required to invest abroad (above certain limits). In December residents are allowed to grant loans to nonresidents to purchase immovable property. In January, 1999 some derivative transactions for nonresidents are permitted. In February there is a gradual ease on the 12-month waiting period and some repatriations funds exempted from exit regulations. In March exports and imports trade ceilings are raised for operations with Thailand. In September commercial banks allowed to enter into some short-term currency swaps with nonresident stockbrokers. In March, 2000 funds from sale of securities purchased by nonresidents can be repatriated without paying exit levy and in June administrative procedures to ease classification of securities as being free from exit levy. September $30^{\text {th }}$ : Some offshore banks are allowed to invest in ringgit assets. December $1^{\text {st. }}$ : foreign-owned banks are allowed to increase domestic credit. In February 2001 the exit levy is abolished for some operations. In May of that year the remaining exit levy is abolished. While in June all controls on nonresidents' futures and options are abolished. In July, resident financial institutions allowed to extend ringgit loans to nonresidents investing in immovable property in Malaysia. In November 2002, resident banks credit levels to finance nonresidents projects in Malaysia are raised. On December $3^{\text {rd }}$ : foreign currency limit for investment abroad by residents is abolished, and payments are liberalized to allow them to be in either ringgit or foreign currency.

\section{Spain (ERM Crisis, 1992)}

September, 1992: Bank of Spain suspends regular money market operations and introduces foreign exchange controls. In October of that year the peseta is devalued and some of the controls a re lifted-in November the remaining foreign exchange controls rescinded.

Thailand (Asian crisis, 1997)

May, 1997: Bank of Thailand (BOT) introduces restrictions on capital account transactions. In June BOT introduces additional measures to limit capital flows. Baht proceeds from sales of stocks required to be converted at the onshore exchange rate. Additional controls are introduced and later in the month a two-tier exchange rate is introduced. In September of that year, Additional controls on invisible and current account transactions are introduced. In January 1998 it is required that proceeds on exports and invisible transactions and current account transfers must be surrendered after 7 days (instead of 15 days). BOT ends two-tier exchange rate regime.at the end of that month

Sources: Banco de España, Bank Negara, Annual Report, various issues, and Bank of Thailand reports, various issues, Conselho Monetario Nacional, Brasil, (Dominguez and Tesar (2004). 
Table 3. The Famous Chilean Case and Other Lesser Deities:

Summary of Key Findings on "Effectiveness"

\begin{tabular}{|c|c|c|c|c|c|}
\hline \multirow[b]{2}{*}{ Study } & \multirow[b]{2}{*}{ Sample } & \multicolumn{2}{|c|}{ Did controls on inflows } & \multirow[b]{2}{*}{$\begin{array}{c}\text { Reduce real } \\
\text { exchange rate } \\
\text { pressures }\end{array}$} & \multirow[b]{2}{*}{$\begin{array}{l}\text { Make monetary } \\
\text { policy more } \\
\text { independent }\end{array}$} \\
\hline & & $\begin{array}{c}\text { Reduce the } \\
\text { volume of } \\
\text { net capital } \\
\text { inflows }\end{array}$ & $\begin{array}{l}\text { Alter the } \\
\text { composition of } \\
\text { flows }\end{array}$ & & \\
\hline \multicolumn{6}{|c|}{ Brazil } \\
\hline $\begin{array}{c}\text { Cardoso \& Goldfajn } \\
\text { (1998) }\end{array}$ & & Yes (ST) & Yes (ST) & & \\
\hline Edison \& Reinhart & 1994 & & & No & No \\
\hline Reinhart \& Smith (1998) & & Yes (ST) & Yes (ST) & & \\
\hline $\begin{array}{c}\text { Ariyoshi, Habermeier, } \\
\text { Laurens, Okter-Robe, } \\
\text { Canales-Kriljenko \& } \\
\text { Kirilenko (2000) }\end{array}$ & 1993-1997 & No & No & No & Yes (ST) \\
\hline \multicolumn{6}{|c|}{ Chile } \\
\hline $\begin{array}{l}\text { De Gregorio, Edwards } \\
\text { \&Valdés (2000) }\end{array}$ & $\begin{array}{l}\text { 1988:I- } \\
\text { 1998:II }\end{array}$ & Yes & Yes (ST) & Yes (ST) & Yes (ST) \\
\hline Edwards (1999)a & & & Yes & No & Yes (ST) \\
\hline Edwards (1999)b & $\begin{array}{c}1991: 6- \\
1998: 9\end{array}$ & No & Yes & No & Yes \\
\hline $\begin{array}{c}\text { Edwards \& Rigobon } \\
\text { (2004) }\end{array}$ & $\begin{array}{l}\text { 1991:1- } \\
\text { 1999:9 }\end{array}$ & & & Yes & \\
\hline $\begin{array}{c}\text { Hernández \& Schmidt- } \\
\text { Hebbel (1999) }\end{array}$ & & Yes (ST) & Yes (ST) & No & Yes \\
\hline $\begin{array}{c}\text { Labán, Larraín \& } \\
\text { Chumacero (1997) } \\
\text { Labán \& Larraín } \\
\text { (1998) }\end{array}$ & 1985-1994 & No & Yes & & \\
\hline $\begin{array}{c}\text { Laurens \& Cardoso } \\
\text { (1998) }\end{array}$ & & Yes (ST) & Yes & No & \\
\hline $\begin{array}{c}\text { Le Fort \& Budnevich } \\
\text { (1997) }\end{array}$ & 1990-1994 & No & Yes & Yes & Yes \\
\hline Reinhart \& Smith (1998) & & Yes (ST) & Yes (ST) & & \\
\hline $\begin{array}{c}\text { Valdés-Prieto \& Soto } \\
\text { (1995) }\end{array}$ & 1987-1995 & No & Yes & No & No \\
\hline $\begin{array}{l}\text { Ariyoshi, Habermeier, } \\
\text { Laurens, Okter-Robe, } \\
\text { Canales-Kriljenko \& } \\
\text { Kirilenko (2000) }\end{array}$ & 1991-1998 & No & No & No & Yes \\
\hline
\end{tabular}

Notes: A blank entry refers to the cases where the study in question did not analyze that particular relationship. An (ST) refers to cases where only short-term effects were detected.

${ }^{1}$ Note that there are several studies on Malaysia's 1998 capital controls targeting outflows. Here, we are referring to the controls on capital inflows introduced in January 1994. 


\section{Table 3 (continued). The Famous Chilean Case and Other Lesser Deities: Summary of Key Findings on "Effectiveness"}

\begin{tabular}{|c|c|c|c|c|c|}
\hline \multirow[b]{2}{*}{ Study } & \multirow[b]{2}{*}{ Sample } & \multicolumn{2}{|c|}{ Did controls on inflows } & \multirow[b]{2}{*}{$\begin{array}{l}\text { Reduce real } \\
\text { exchange rate } \\
\text { pressures }\end{array}$} & \multirow[b]{2}{*}{$\begin{array}{l}\text { Make monetary } \\
\text { policy more } \\
\text { independent }\end{array}$} \\
\hline & & $\begin{array}{l}\text { Reduce the } \\
\text { volume of } \\
\text { net capital } \\
\text { inflows }\end{array}$ & $\begin{array}{l}\text { Alter the } \\
\text { composition of } \\
\text { flows }\end{array}$ & & \\
\hline \multicolumn{6}{|c|}{ Colombia } \\
\hline $\begin{array}{l}\text { Le Fort \& Budnevich } \\
\text { (1997) }\end{array}$ & 1990-1995 & Yes (ST) & Yes & Yes & Yes \\
\hline Reinhart \& Smith (1998) & & No & No & & \\
\hline $\begin{array}{l}\text { Ariyoshi, Habermeier, } \\
\text { Laurens, Okter-Robe, } \\
\text { Canales-Kriljenko \& } \\
\text { Kirilenko (2000) }\end{array}$ & 1993-1998 & No & No & No & Yes \\
\hline \multicolumn{6}{|c|}{ Czech Republic } \\
\hline Reinhart \& Smith (1998) & & No & Yes (ST) & & \\
\hline \multicolumn{6}{|c|}{ Malaysia (1989) $^{1}$} \\
\hline Reinhart \& Smith (1998) & & Yes & Yes & & \\
\hline \multicolumn{6}{|c|}{ Malaysia (1994) } \\
\hline $\begin{array}{l}\text { Ariyoshi, Habermeier, } \\
\text { Laurens, Okter-Robe, } \\
\text { Canales-Kriljenko \& } \\
\text { Kirilenko (2000) }\end{array}$ & 1994 & Yes & Yes & Yes (ST) & Yes \\
\hline \multicolumn{6}{|l|}{ Arivoshi. Habermeier. } \\
\hline $\begin{array}{l}\text { Ariyoshi, Habermeier, } \\
\text { Laurens, Okter-Robe, } \\
\text { Canales-Kriljenko \& } \\
\text { Kirilenko (2000) }\end{array}$ & $1995-1997$ & Yes & Yes & Yes & Yes \\
\hline
\end{tabular}

Notes: A blank entry refers to the cases where the study in question did not analyze that particular relationship. An (ST) refers to cases where only short-term effects were detected.

${ }^{1}$ Note that there are several studies on Malaysia's 1998 capital controls targeting outflows. Here, we are referring to the controls on capital inflows introduced in January 1994. 
Table 4. The Famous Malaysian Case and Other Lesser Deities: Summary of Key Findings on "Effectiveness"

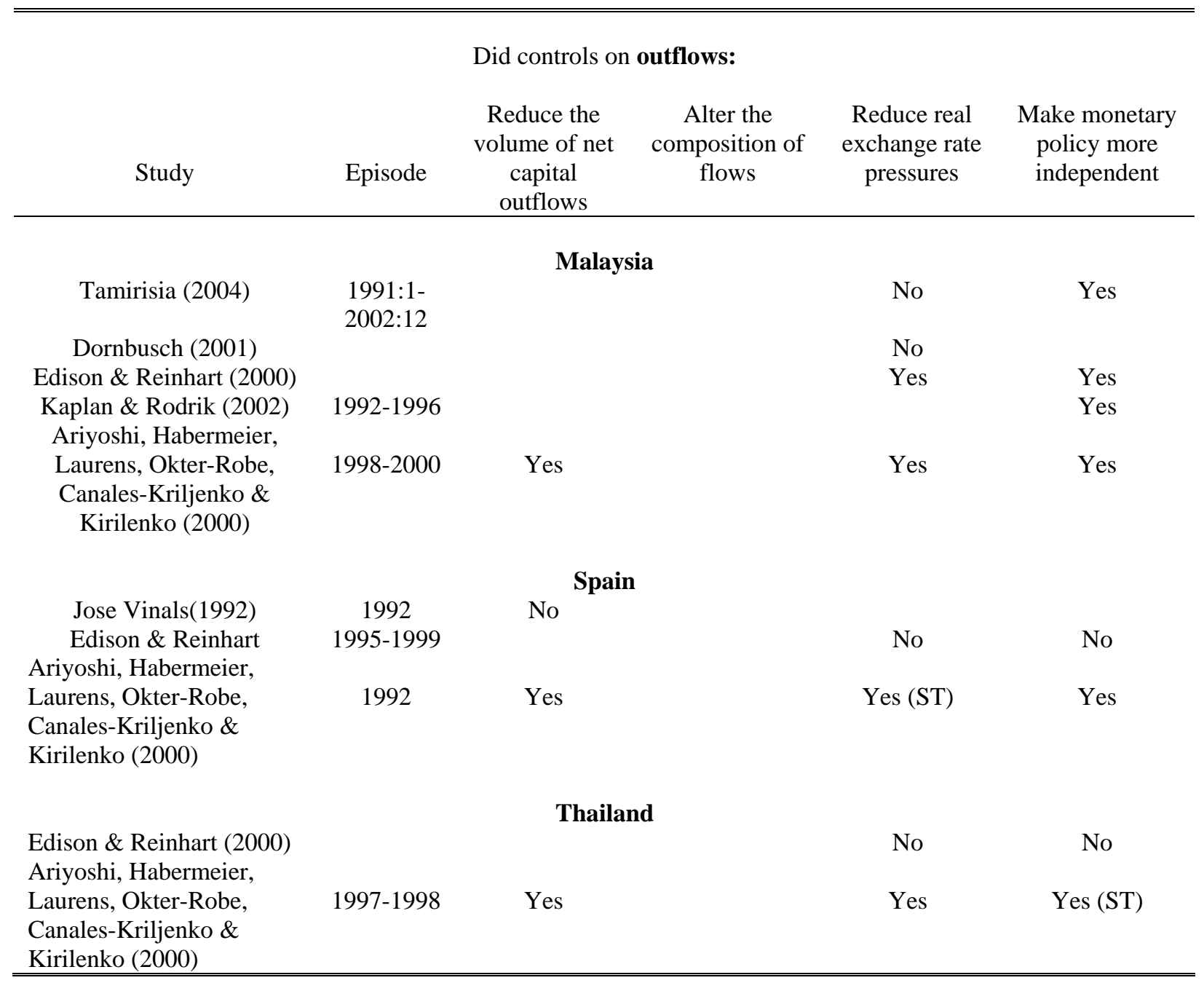

Notes: A blank entry refers to the cases where the study in question did not analyze that particular relationship. An (ST) refers to cases where only short-term effects were detected. 
Table 5. The "Others" - Multicountry Studies

Summary of Key Findings on "Effectiveness"

\begin{tabular}{|c|c|c|c|c|c|}
\hline \multicolumn{6}{|c|}{ Did controls on inflows: } \\
\hline Study & Sample & $\begin{array}{l}\text { Reduce the } \\
\text { volume of net } \\
\text { capital inflows }\end{array}$ & $\begin{array}{l}\text { Alter the } \\
\text { composition } \\
\text { of flows }\end{array}$ & $\begin{array}{l}\text { Reduce real } \\
\text { exchange rate } \\
\text { pressures }\end{array}$ & $\begin{array}{c}\text { Make monetary } \\
\text { policy more } \\
\text { independent }\end{array}$ \\
\hline $\begin{array}{c}\text { Montiel \& } \\
\text { Reinhart } \\
\text { (1999) }\end{array}$ & $\begin{array}{l}\text { Indonesia, Malaysia, } \\
\text { Philippines, Sri Lanka, } \\
\text { Thailand, Argentina, } \\
\text { Brazil, Chile, Colombia, } \\
\text { Costa Rica, Mexico, Czech } \\
\text { Republic, Egypt, Kenya } \\
\text { and Uganda (1990-1996) }\end{array}$ & No & Yes (ST) & & No \\
\hline $\begin{array}{l}\text { Reinhart } \\
\text { \& Smith } \\
\text { (1998) }\end{array}$ & $\begin{array}{l}\text { Brazil, Chile, Colombia, } \\
\text { Czech Republic, Malaysia, } \\
\text { Mexico, } \\
\text { Thailand, Indonesia, and } \\
\text { Philippines }\end{array}$ & Yes (ST) & Yes (ST) & & \\
\hline $\begin{array}{c}\text { Kaplan \& } \\
\text { Rodrik } \\
\text { (2002) }\end{array}$ & $\begin{array}{l}\text { Korea, Thailand, } \\
\text { Indonesia, Malaysia } \\
\text { (monthly and quarterly } \\
\text { data for 1992-1996 -before } \\
\text { crisis- and from crisis time } \\
\text { and } 1 \text { year ahead) }\end{array}$ & & & & Yes \\
\hline $\begin{array}{c}\text { Edison \& } \\
\text { Reinhart } \\
\text { (1999) }\end{array}$ & $\begin{array}{l}\text { Spain (1991-1993), and } \\
\text { 1995-1999 for Brazil, } \\
\text { Malaysia, and Thailand. } \\
\text { Control group: Philippines } \\
\text { and South Korea (daily } \\
\text { data) }\end{array}$ & & & No & No \\
\hline $\begin{array}{c}\text { Miniane \& } \\
\text { Rogers } \\
(2004)\end{array}$ & $\begin{array}{l}\text { Australia, Austria, } \\
\text { Belgium, Canada, Chile, } \\
\text { Colombia, Denmark, } \\
\text { Finland, France, Germany, } \\
\text { Greece, India, Italy, Japan, } \\
\text { Korea, Malaysia, Mexico, } \\
\text { The Netherlands, Norway, } \\
\text { The Philippines, Portugal, } \\
\text { South Africa, Spain, } \\
\text { Sweden, Turkey, UK. } \\
\text { (monthly data for 1971:1- } \\
\text { 1998:12) }\end{array}$ & & & Yes (ST) & No \\
\hline
\end{tabular}

Notes: A blank entry refers to the cases where the study in question did not analyze that particular relationship. An (ST) refers to cases where only short-term effects were detected. 
Table 6. Summary of Results By Country and Multi-country Studies

\begin{tabular}{ccccc}
\hline \hline Study & $\begin{array}{c}\text { Did controls on inflows: } \\
\text { Reduce the } \\
\text { volume of } \\
\text { net capital } \\
\text { inflows }\end{array}$ & $\begin{array}{c}\text { Alter the } \\
\text { composition } \\
\text { of flows }\end{array}$ & $\begin{array}{c}\text { Reduce real } \\
\text { exchange rate } \\
\text { pressures }\end{array}$ & $\begin{array}{c}\text { Make } \\
\text { monetary } \\
\text { policy more } \\
\text { independent }\end{array}$ \\
\hline Complete Sample & Unclear & Yes & Unclear & Yes \\
Control on Inflows & Unclear & Unclear & No & Unclear \\
Brazil & Unclear & Yes & Unclear** & Yes \\
Chile & Unclear & Unclear & Unclear & Yes \\
Colombia & No & Yes & & \\
Malaysia (1989) & Yes & Yes & Yes & Yes \\
Malaysia (1994) & Yes & Yes & Yes & Yes \\
Thailand & Yes & Yes & & Yes \\
Control on Outflows & & & Unclear \\
Malaysia (1998) & & & Unclear & Unclear \\
Spain & Unclear & & Yes \\
Thailand & Yes & & Yes & No \\
Multi-country studies & Yes & Yes & \\
\hline \hline
\end{tabular}

Note: Yes stands for yes, it worked; No for no, it did not work; Unclear for mixed results; and blanks for results not reported. 
Table 7. Capital Inflows: The Indices

\begin{tabular}{ccccccc}
\hline \hline Country & Index & $\begin{array}{c}\text { Reduce } \\
\text { the } \\
\text { volume of } \\
\text { net } \\
\text { capital } \\
\text { inflows }\end{array}$ & $\begin{array}{c}\text { Alter the } \\
\text { composition of } \\
\text { flows }\end{array}$ & $\begin{array}{c}\text { Reduce real } \\
\text { exchange rate } \\
\text { pressures }\end{array}$ & $\begin{array}{c}\text { Make } \\
\text { Monetary } \\
\text { Policy } \\
\text { Independent } \\
\text {. }\end{array}$ & $\begin{array}{c}\text { Country } \\
\text { Average }\end{array}$ \\
\hline Brazil & CCE & 0.00 & 0.00 & -0.67 & 0.00 & 0 \\
& WCCE & 0.35 & 0.35 & -0.275 & -0.225 & 0.05 \\
Chile & CCE & -0.09 & 0.64 & -0.27 & 0.45 & 0.18 \\
& WCCE & 0.03 & 0.67 & -0.27 & 0.29 & 0.18 \\
Colombia & CCE & -0.33 & -0.33 & 0.00 & 0.67 & 0.00 \\
& WCCE & -0.17 & -0.17 & 0.00 & 0.07 & -0.07 \\
Czech & CCE & -1.00 & 1.00 & 0.00 & 0.00 & 0.00 \\
Republic & WCCE & -0.50 & 0.10 & 0.00 & 0.00 & -0.10 \\
& & & & & & \\
Malaysia & CCE & 1.00 & 1.00 & 0.50 & 0.50 & 0.75 \\
& WCCE & 0.30 & 0.30 & 0.05 & 0.05 & 0.18 \\
Thailand & CCE & 1.00 & 1.00 & 1.00 & 1.00 & 1.00 \\
& WCCE & 0.10 & 0.10 & 0.10 & 0.10 & 0.10 \\
& & & & & & \\
\hline \hline
\end{tabular}

Sources: Appendix Table 1 and sources cited therein.

Table 8.Capital Outflows: The Indices

\begin{tabular}{|c|c|c|c|c|c|c|}
\hline Country & Index & $\begin{array}{l}\text { Reduce } \\
\text { the } \\
\text { volume of } \\
\text { net } \\
\text { capital } \\
\text { inflows } \\
\end{array}$ & $\begin{array}{l}\text { Alter the } \\
\text { composition of } \\
\text { flows }\end{array}$ & $\begin{array}{c}\text { Reduce real } \\
\text { exchange rate } \\
\text { pressures }\end{array}$ & $\begin{array}{c}\text { Make } \\
\text { Monetary } \\
\text { Policy } \\
\text { Independent }\end{array}$ & $\begin{array}{l}\text { Country } \\
\text { Average }\end{array}$ \\
\hline \multirow{2}{*}{ Malaysia } & CCE & 0.20 & 0.00 & 0.00 & 0.80 & 0.25 \\
\hline & WCCE & 0.02 & 0.00 & 0.00 & 0.62 & 0.16 \\
\hline \multirow{2}{*}{ Spain } & CCE & 0.50 & 0.00 & 0.50 & 0.50 & 0.38 \\
\hline & WCCE & 0.05 & 0.00 & 0.20 & 0.20 & 0.11 \\
\hline \multirow{2}{*}{ Thailand } & CCE & 0.50 & 0.00 & 0.00 & 0.00 & 0.13 \\
\hline & WCCE & 0.05 & 0.00 & -0.50 & -0.50 & -0.24 \\
\hline
\end{tabular}

Sources: Appendix Table 2 and sources cited therein. 
Table 9. Multi-Country Studies: The Indices

\begin{tabular}{ccccc}
\hline \hline Index & $\begin{array}{c}\text { Reduce the } \\
\text { volume of net } \\
\text { capital } \\
\text { inflows }\end{array}$ & $\begin{array}{c}\text { Alter the } \\
\text { composition of } \\
\text { flows }\end{array}$ & $\begin{array}{c}\text { Reduce real } \\
\text { exchange rate } \\
\text { pressures }\end{array}$ & $\begin{array}{c}\text { Make monetary } \\
\text { policy more } \\
\text { independent }\end{array}$ \\
\hline CCE & 0.00 & 0.40 & 0.00 & -0.40 \\
WCCE & -0.10 & 0.30 & 0.00 & -0.40 \\
\hline \hline
\end{tabular}

Sources: Appendix Table 3 and sources cited therein. 
Appendix Table 1

Capital Inflows: Methodology and Degree of Methodological Rigor

Study

Sample

Methodology

Cardoso \& Goldfajn (1998)

Edison \& Reinhart (1999)

Reinhart \& Smith (1998)

Ariyoshi, Habermeier,

Laurens, Okter-

Robe, Canales-

Kriljenko \&

Kirilenko (2000)

De Gregorio,

Edwards \&Valdés (2000)

Edwards (1999)a

Edwards (1999)b

Edwards \& Rigobon (2004)
1988:11995:12

1995-

2001

1994-

1996

1993-

1997

1988:I-

1998:II

1994:10 - GARCH for changes in the short term central bank nominal interest rate, and changes in the log of the

1999:1 stock market index, using daily data. Descriptive analysis of the effects of capital controls on the composition of capital inflows, and domestic interest rates and monetary policy independence.

1991:6- Descriptive analysis of the composition of capital flows during capital controls times. VAR on the effects

1998:9

of capital controls on the real exchange rate. GARCH for changes in the short term central bank nominal interest rate, and changes in the log of the stock market index.

1991:1- Using stochastic calculus, they compute the shadow exchange rate and its bands. GARCH (effect of 1999:9 capital controls on propagation of external shocks. Estimate a mean and a variance equation.
Econometric

Rigor

High

High

Medium

Low 


\section{Chile (continued)}

Hernández \& Schmidt-Hebbel (1999)

Labán, Larraín \& Chumacero (1997)

\section{Labán \& Larraín} (1998)

Laurens \& Cardoso (1998)

Le Fort \&

Budnevich (1997)

Reinhart \& Smith (1998)
1989-

and

1998:7-

1999:6

1985-

1985-

1996

1985:I-

1994:IV

1990-

1994

1990

1994

Least squares estimation, controlling for spurious correlation, endogeniety of the RHS regressors,

estimation also included

Estimation of a special case of non-linear models in which a particular variable may adopt a certain law of motion conditional on an observation passed a threshold (special case of Markov Switching Regime

Models, with the threshold replacing the transition matrix). They run a full sample parsimonious regression for each series, to determine variables to include in the threshold process; for given choice of threshold variable, they estimated the model and got the p-value associated with a null of a unique stable representation; if the latter is rejected in favor of threshold process chose the threshold variable that minimizes the sum of squares of residuals; and reduce the threshold model to a parsimonious representation.

Descriptive analysis of events, describing the context for implementing capital controls and the main macroeconomic effects.

Linear and Cubic approximations of net inflows as primarily of interest rate differentials.

Descriptive analysis of events, describing the context for implementing capital controls and the main macroeconomic.

Event comparison through time- rescaling (labeling the implementation of controls as period " $\mathrm{t}$ ", and analyzing the evolution of the series in " $\mathrm{t}-1$ ", and through " $\mathrm{t}+2$ ". Detailed chronological description of the various measures applied in each economy 
Appendix Table 1 (continued)

Capital Inflows: Methodology and Degree of Methodological Rigor

\begin{tabular}{|c|c|c|c|}
\hline Study & Sample & Methodology & $\begin{array}{c}\text { Econometric } \\
\text { Rigor }\end{array}$ \\
\hline \multicolumn{4}{|c|}{ Chile (concluded) } \\
\hline $\begin{array}{l}\text { Valdés-Prieto \& } \\
\text { Soto } \\
\text { (1995) }\end{array}$ & $\begin{array}{l}1987- \\
1995\end{array}$ & $\begin{array}{l}\text { Error-correction representation (that is efficient) with a two-step procedure: (i) OLS estimation of the real } \\
\text { exchange rate on a set of explanatory variables to contrast the estimated residuals; and (ii) use these } \\
\text { residuals to estimate by OLS an error correction equation measuring the deviation of the dependent } \\
\text { variable from its long term equilibrium level (given by (i)). They checked for several endogeneity and } \\
\text { simultaneity biases. They also looked at the effect of controls on short term credit }\end{array}$ & High \\
\hline $\begin{array}{l}\text { Le Fort \& } \\
\text { Budnevich } \\
\text { (1997) }\end{array}$ & $\begin{array}{l}1990- \\
1995\end{array}$ & $\begin{array}{l}\text { Colombia } \\
\text { Descriptive analysis of events, describing the context for implementing capital controls and the main } \\
\text { macroeconomic. }\end{array}$ & Low \\
\hline $\begin{array}{c}\text { Reinhart \& Smith } \\
\text { (1998) }\end{array}$ & & $\begin{array}{l}\text { Event comparison through time- rescaling (labeling the implementation of controls as period " } \mathrm{t} \text { ", and } \\
\text { analyzing the evolution of the series in " } \mathrm{t}-1 \text { ", and through " } \mathrm{t}+2 \text { ". Detailed chronological description of } \\
\text { the various measures applied in each economy }\end{array}$ & Medium \\
\hline $\begin{array}{c}\text { Ariyoshi, } \\
\text { Habermeier, } \\
\text { Laurens, Okter- } \\
\text { Robe, Canales- } \\
\text { Kriljenko \& } \\
\text { Kirilenko (2000) }\end{array}$ & $\begin{array}{l}1993- \\
1998\end{array}$ & $\begin{array}{l}\text { Extensive descriptive and comparative country-studies analysis of time-series in each episode, } \\
\text { dividing facts according to controls on capital inflows (limiting short-term flows), control on capital } \\
\text { outflows (financial crises), extensive exchange controls (financial crises), long standing controls and } \\
\text { their liberalization, rapid liberalization }\end{array}$ & Low \\
\hline $\begin{array}{c}\text { Reinhart \& Smith } \\
\text { (1998) }\end{array}$ & $\begin{array}{l}1994- \\
1997\end{array}$ & $\begin{array}{l}\text { Czech Republic } \\
\text { Event comparison through time- rescaling (labeling the implementation of controls as period "t”, and } \\
\text { analyzing the evolution of the series in " } \mathrm{t}-1 \text { ", and through " } \mathrm{t}+2 \text { ". Detailed chronological description of } \\
\text { the various measures applied in each economy }\end{array}$ & Medium \\
\hline $\begin{array}{c}\text { Reinhart \& Smith } \\
\text { (1998) }\end{array}$ & $\begin{array}{l}1993- \\
1996\end{array}$ & $\begin{array}{l}\text { Malaysia (1989) } \\
\text { Event comparison through time- rescaling (labeling the implementation of controls as period “t”, and } \\
\text { analyzing the evolution of the series in " } \mathrm{t}-1 \text { ", and through " } \mathrm{t}+2 \text { ". Detailed chronological description of } \\
\text { the various measures applied in each economy }\end{array}$ & Medium \\
\hline
\end{tabular}


Appendix Table 1 (concluded)

Capital Inflows: Methodology and Degree of Methodological Rigor

\begin{tabular}{|c|c|c|c|}
\hline Study & Sample & Methodology & $\begin{array}{c}\text { Econometric } \\
\text { Rigor }\end{array}$ \\
\hline $\begin{array}{c}\text { Ariyoshi, } \\
\text { Habermeier, } \\
\text { Laurens, Okter- } \\
\text { Robe, Canales- } \\
\text { Kriljenko \& } \\
\text { Kirilenko (2000) }\end{array}$ & 1994 & $\begin{array}{l}\text { Malaysia (1994) } \\
\text { Extensive descriptive and comparative country-studies analysis of time-series in each episode, } \\
\text { dividing facts according to controls on capital inflows (limiting short-term flows), control on capital } \\
\text { outflows (financial crises), extensive exchange controls (financial crises), long standing controls and } \\
\text { their liberalization, rapid liberalization }\end{array}$ & Low \\
\hline $\begin{array}{c}\text { Ariyoshi, } \\
\text { Habermeier, } \\
\text { Laurens, Okter- } \\
\text { Robe, Canales- } \\
\text { Kriljenko \& } \\
\text { Kirilenko (2000) }\end{array}$ & 1995-1997 & $\begin{array}{l}\text { Thailand } \\
\text { Extensive descriptive and comparative country-studies analysis of time-series in each episode, } \\
\text { dividing facts according to controls on capital inflows (limiting short-term flows), control on capital } \\
\text { outflows (financial crises), extensive exchange controls (financial crises), long standing controls } \\
\text { and their liberalization, rapid liberalization }\end{array}$ & Low \\
\hline
\end{tabular}


Appendix Table 2

Capital Outflows: Methodology and Degree of Methodological Rigor

Study

Tamirisia (2004)

Dornbusch (2001)

Edison \& Reinhart (2000)

Kaplan \& Rodrik (2002)

Ariyoshi,

Habermeier, Laurens, OkterRobe, CanalesKriljenko \&

Kirilenko (2000)

Jose Viñals(1992)

Edison \& Reinhart (1999)
1991:1- Error-correction model. Series on net foreign portfolio assets are by foreign portfolio assets to isolate country-specific effects

Descriptive analysis of different variables

Test for equality of moments and changes in persistence between capital controls and no controls, principal components analysis; block exogeneity tests (VAR) for causality; GARCH for the effects of controls on volatility; and Wald tests for structural brakes over a rolling window

1992- Shifted difference in differences to separate the counterfactual of capital controls versus IMF-basedprogram recovery. This methodology enables the authors to re-schedule the episodes in terms of the timing of the crises (shifted). The difference in differences allows them to capture the comparison effect of the recovery with capital controls vis a vis with a successful IMF program, controlling for exogenous and country-specific effects (static and dynamics)

Extensive descriptive and comparative country-studies analysis of time-series in each episode,

dividing facts according to controls on capital inflows (limiting short-term flows), control on capital outflows (financial crises), extensive exchange controls (financial crises), long standing controls and their liberalization, rapid liberalization
Low

High

Low

\section{Spain}

1992 Descriptive analysis of economic policy measures and its effect on various macroeconomic variables

1991- Test for equality of moments and changes in persistence between capital controls and no controls, 1993 principal components analysis; block exogeneity tests (VAR) for causality; GARCH for the effects 
Appendix Table 2 (continued)

Capital Outflows: Methodology and Degree of Methodological Rigor

Ariyoshi,

Habermeier,

Laurens, Okter-

Robe, Canales-

Kriljenko \&

Kirilenko (2000)

Edison \& Reinhart (2000)

Ariyoshi,

Habermeier,

Laurens, Okter-

Robe, Canales-

Kriljenko \&

Kirilenko (2000)
Extensive descriptive and comparative country-studies analysis of time-series in each episode,

dividing facts according to controls on capital inflows (limiting short-term flows), control on capital outflows (financial crises), extensive exchange controls (financial crises), long standing controls and their liberalization, rapid liberalization

\section{Thailand}

1995- Test for equality of moments and changes in persistence between capital controls and no controls, principal components analysis; block exogeneity tests (VAR) for causality; GARCH for the effects of controls on volatility; and Wald tests for structural brakes over a rolling window

Extensive descriptive and comparative country-studies analysis of time-series in each episode, dividing facts according to controls on capital inflows (limiting short-term flows), control on capital

1998 outflows (financial crises), extensive exchange controls (financial crises), long standing controls and their liberalization, rapid liberalization 
Appendix Table 3

Multi-country Studies: Methodology and Degree of Methodological Rigor

\begin{tabular}{|c|c|c|c|}
\hline Study & Sample & Methodology & Econometric Rigor \\
\hline $\begin{array}{l}\text { Montiel \& Reinhart } \\
\text { (1999) }\end{array}$ & 1990-1996 & $\begin{array}{l}\text { They construct indices to measure incidence and intensity of capital account restrictions. Estimation } \\
\text { of fix-effect panel regressions to explain volume and composition of capital flows. Results are } \\
\text { checked for robustness by IV estimations. Covers Indonesia, Malaysia, Philippines, Sri Lanka, } \\
\text { Thailand, Argentina, Brazil, Chile, Colombia, Costa Rica, Mexico, Czech Republic, Egypt, Kenya } \\
\text { and Uganda }\end{array}$ & High \\
\hline $\begin{array}{l}\text { Reinhart \& Smith } \\
\text { (1998) }\end{array}$ & 1990-1997 & $\begin{array}{l}\text { Event comparison through time- rescaling (labeling the implementation of controls as period " } t \text { ”, and } \\
\text { analyzing the evolution of the series in "t-1", and through " } t+2 \text { ”. Detailed chronological description } \\
\text { of the various measures applied in each economy. Covers Brazil, Chile, Colombia, Czech Republic, } \\
\text { Malaysia, Mexico, Thailand, Indonesia, and Philippines. }\end{array}$ & Intermediate \\
\hline $\begin{array}{l}\text { Kaplan \& Rodrik } \\
\text { (2002) }\end{array}$ & 1992-1996 & $\begin{array}{l}\text { Shifted difference in differences to separate the counterfactual of capital controls versus IMF-based- } \\
\text { program recovery. This methodology enables the authors to re-schedule the episodes in terms of the } \\
\text { timing of the crises (shifted). The difference in differences allows them to capture the comparison } \\
\text { effect of the recovery with capital controls vis a vis with a successful IMF program, controlling for } \\
\text { exogenous and country-specific effects (static and dynamics). Covers Korea, Thailand, Indonesia, } \\
\text { Malaysia (monthly and quarterly data for 1992-1996 -before crisis- and from crisis time and } 1 \text { year } \\
\text { ahead) }\end{array}$ & \\
\hline $\begin{array}{l}\text { Edison \& Reinhart } \\
\text { (1999) }\end{array}$ & 1991-1999 & $\begin{array}{l}\text { Test for equality of moments and changes in persistence between capital controls and no controls, } \\
\text { principal components analysis; block exogeneity tests (VAR) for causality; GARCH for the effects of } \\
\text { controls on volatility; and Wald tests for structural brakes over a rolling window. Covers Spain } \\
\text { (1991-1993), and 1995-1999 for Brazil, Malaysia, and Thailand. Control group: Philippines and } \\
\text { South Korea }\end{array}$ & High \\
\hline
\end{tabular}


Appendix Table 3 (concluded)

Multi-country Studies: Methodology and Degree of Methodological Rigor

\begin{tabular}{ccl}
\hline \hline Study & Sample & \\
& & \\
\hline $\begin{array}{c}\text { Miniane \& Rogers } \\
\text { (2004) }\end{array}$ & $1971: 1-$ & $\begin{array}{l}\text { Panel VAR and individual country VAR of commodity prices, US industrial production , US } \\
\text { consumers prices, foreign industrial production, foreign interest rates, US Fed Funds Rate, non- } \\
\text { borrowed reserves to reserves ratio and nominal exchange rate in response to a } 25 \text { basis points } \\
\text { increase in the Fed Funds Rate. For the country level VAR they regress each country separately, } \\
\text { compute the cumulative exchange rate and interest rate responses, and finally regress country- } \\
\text { specific responses on the values of capital control index, exchange rate regime, degree of } \\
\text { dollarization, and trade integration. Covers Australia, Austria, Belgium, Canada, Chile, Colombia, } \\
\text { Denmark, Finland, France, Germany, Greece, India, Italy, Japan, Korea, Malaysia, Mexico, The } \\
\text { Netherlands, Norway, The Philippines, Portugal, South Africa, Spain, Sweden, Turkey, UK }\end{array}$ \\
\hline \hline
\end{tabular}




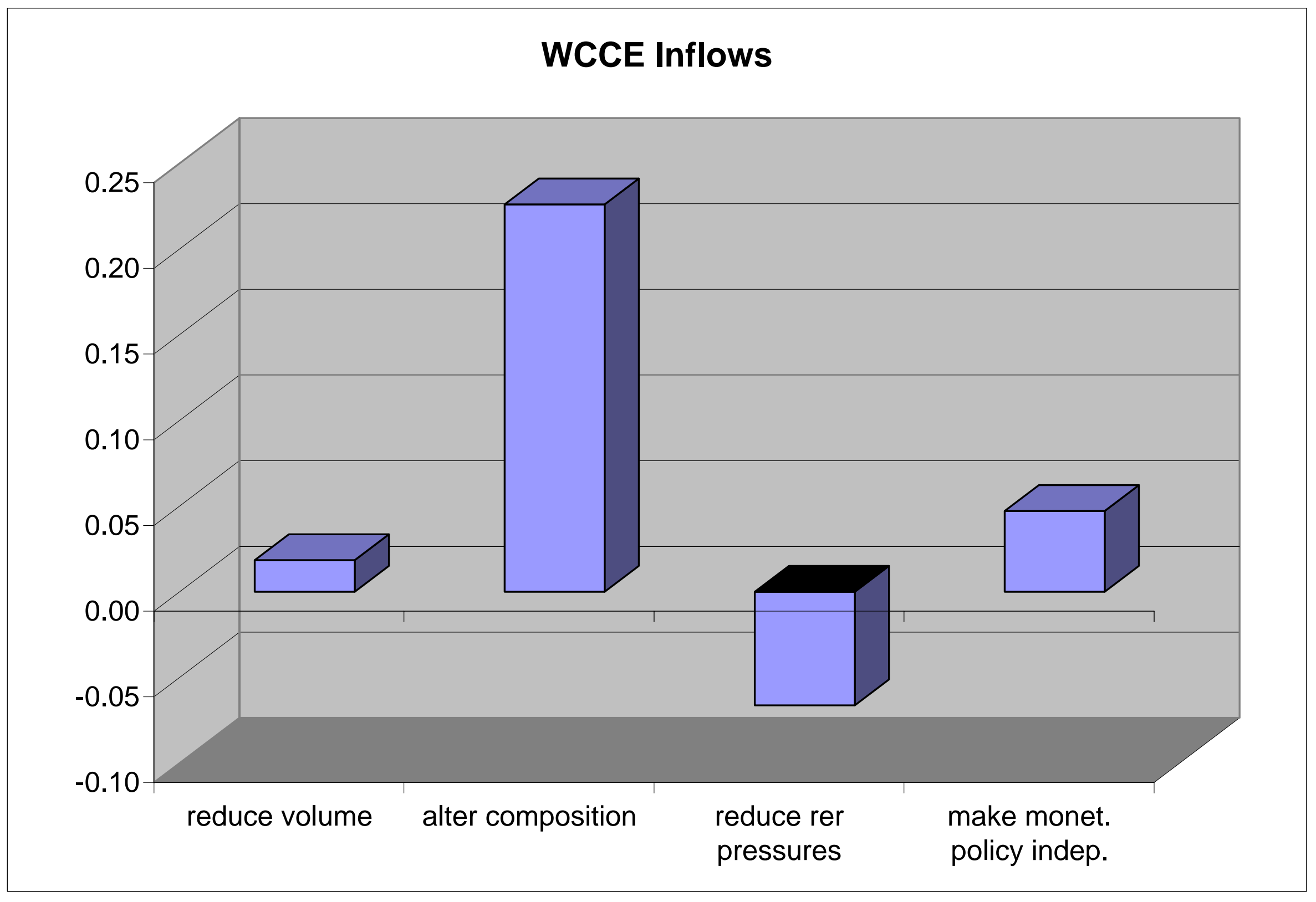




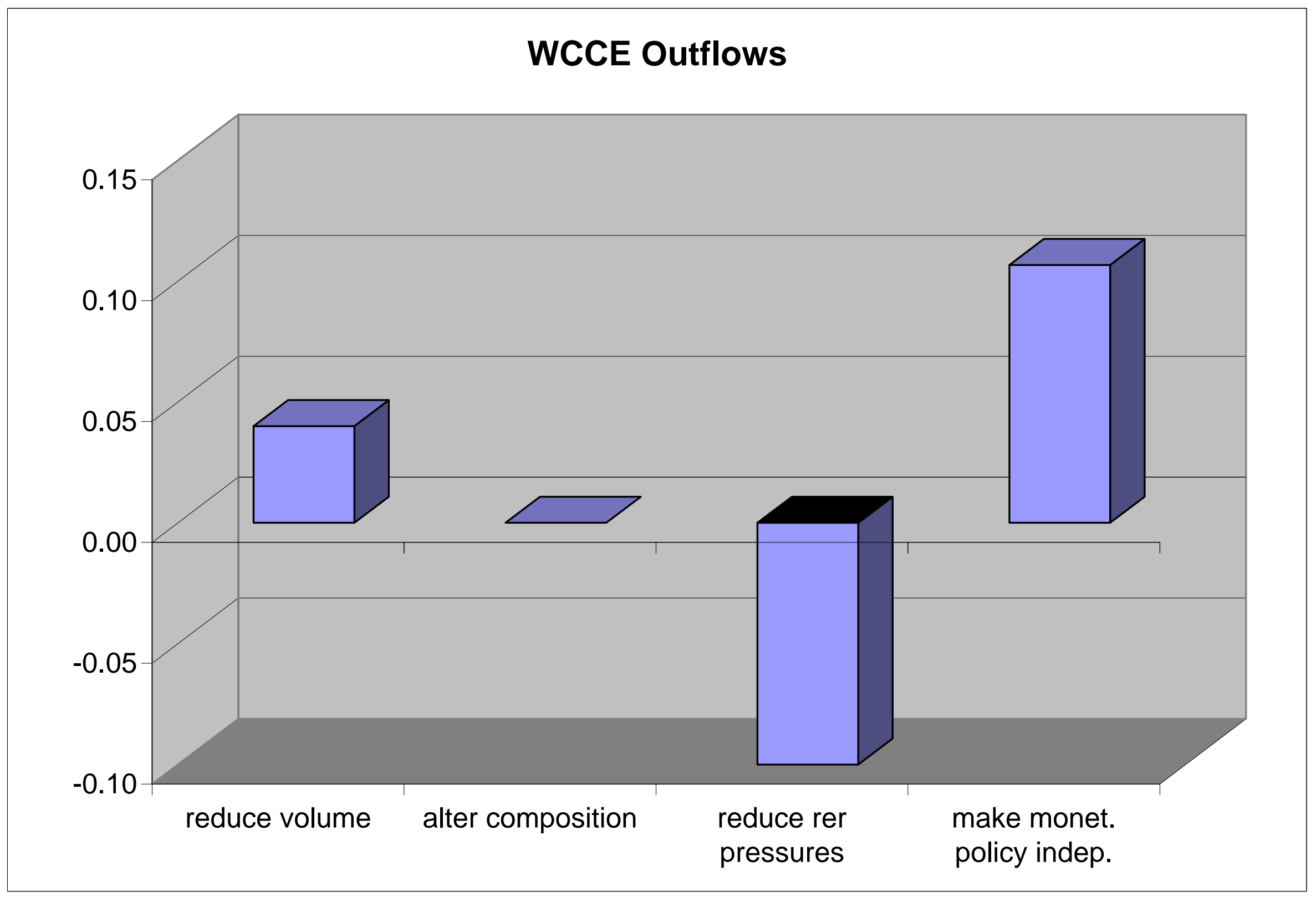




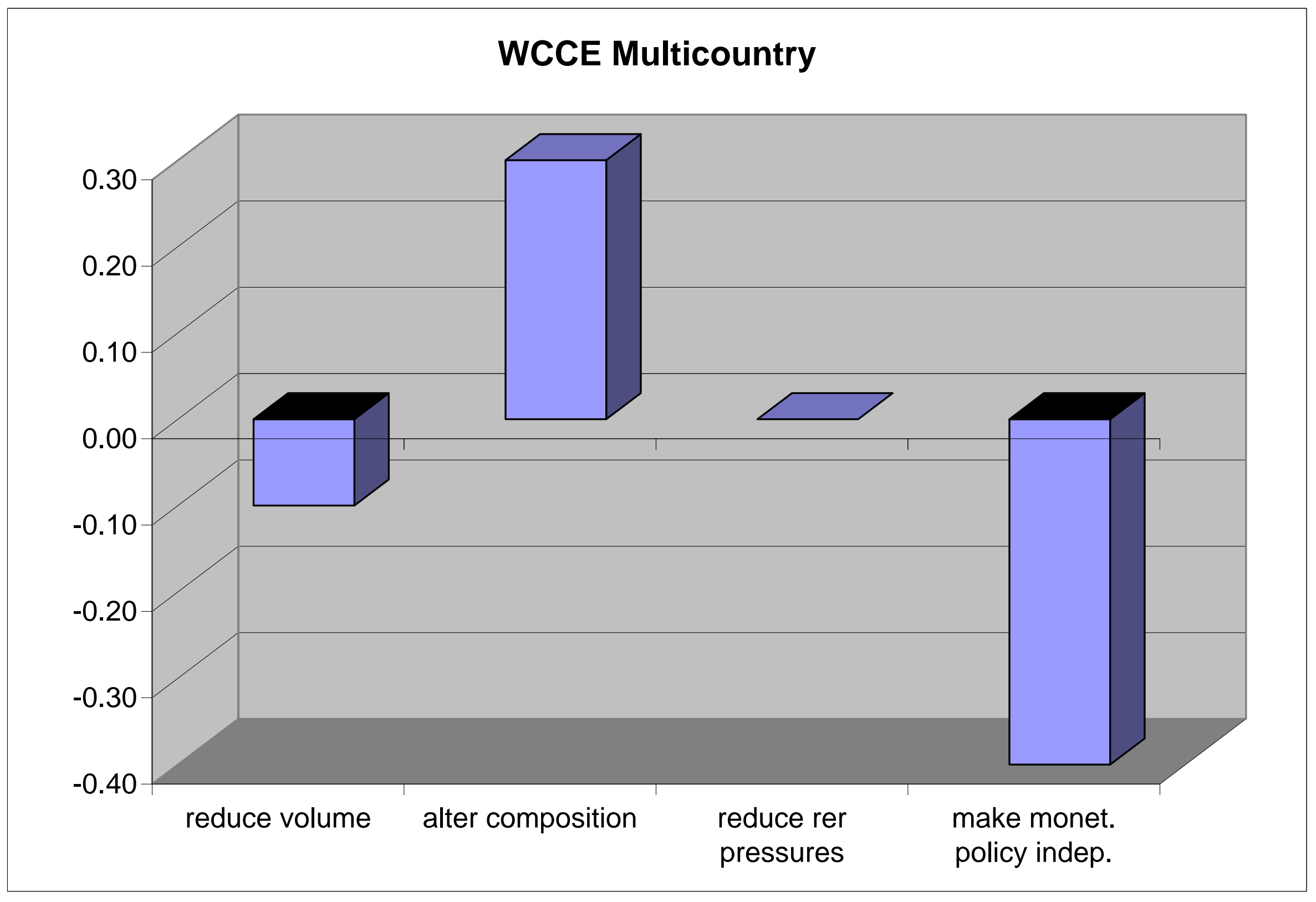

